\title{
Studies of the Glycine Cleavage Enzyme System in Brain from Infants with Glycine Encephalopathy
}

\author{
THOMAS I. PIERRY, ${ }^{\prime 3}$ NADINI: UROUHART, ANI) SHIRIIYY HANSHEN \\ Departme'nt of Pharmacology, Lniversity of British Columbia. Vanconser. British Columbia. Canada \\ ()RVAL. A. MAMIR \\ Mass Spectrometry Unit. Royal V'ictoria Hospital, Montreal. Quadere. Canada
}

\begin{abstract}
Summary
Glycine content and enzyme activity of the glycine cleavage system were compared in autopsied brain from five infants dying with glycine encephalopathy and four control infants, including two with other types of hyperglycinemia. Glycine content was elevated 2- to 8-fold and glycine cleavage enzyme activity was undetectable in the brains of the glycine encephalopathy patients. Glycine content and enzyme activity were normal in the brains of the control patients, including one with ketotic hyperglycinemia secondary to methylmalonic acidemia. Prolonged dialysis failed to restore glycine cleavage enzyme activity in brain homogenates of glycine encephalopathy patients, and these homogenates failed to inhibit enzyme activity when added to homogenates of control brain. Radioactive bicarbonate was converted to radioactive glycine by control brain, but not by glycine encephalopathy brain. This finding, together with the results of recombination experiments between solubilized human brain enzymes and purified protein components of the bacterial glycine cleavage system of Arthrohacter globiformis, indicates that the enzyme defect in glycine encephalopathy involves at least the second or $H$ protein of the 4-protein glycine cleavage enzyme system.
\end{abstract}

\section{Speculation}

The severe neurologic syndrome that characterizes glycine encephalopathy, in contrast to some other forms of hyperglycinemia, is probably caused by absence of glycine cleavage enzyme activity and marked elevation of glycine content in infantile brain. Since symptoms of this inherited disorder only appear shortly after birth, a firmly bound endogenous inhibitor of the glycine cleavage enzyme may accumulate in brain of affected infants, who have been protected during fetal life by clearance of the putative inhibitor across the placenta.

Plasma glycine concentrations are abmormatly high in a variety of different genetically determined metabolic disorders of infants and children. These disorders are generally classified as ketotic hyperglycinemias if ketracidosis is present. and if an unusual organic acid accumulates in blood and tisstes and is excreted in the urine. For example. hyperglycinemia often accompanies propionic acidemiat (2) and methylmalonic acidemia (12). and it also has been observed in some patients with isovaleric acidemia (1) and $\beta$-ketothiolase deficiency (7). When ketoscidosis is absent and no unusual organic acids can be detected in blood or urine. hyperglycinemias are termed nonketotic. However, there atre marked cinical differences among patients with so-called nonketotic hyperglycincmia. Some show little evidence of seri- ous illness and have no neurologic symptoms. ()thers exhibit a severe neurologic disorder which commences within a few days or weeks of birth. It is characterized by lethargy, intractable scizures, spasticity. mental retardation. and usually by carly deith (16).

We found $(20)$ that three infants with this latter syndrome had greatly clevated glycine concentrations in their corebrospinal fluid (CSF), in contrast to the normal glycine levels found in the (SF of other hyperglycinemic patients who had no neurologic symptoms. Glycine content was matredly elevated in the brains of two infants who died. (ilycinc cleavage cnzyme activity was not detectable in the brains of these infants, although it wits present in their livers at atutepsy. We suggested the term glycine encephalopathy to describe this syndrome, and to differentiate it from other nonketotic hyperglycinemias (20)

The glycine cleavage enzyme system is a complex of four different interating proteins $(15)$. We describe here experiments carried out on autopsied brain from 5 infants with glycine encephalopathy and four control infants that were designed to localize the exald site of the defect in this congme system. We have also sought to explain why infants with glycine crecphalopathy are apparently nomal during intrauterine life. but become severely affected soon after birth.

\section{PATIENTS}

Patients $/$ and 2 were sisters. aged 10 months and 8 months at death, whom we have described previously (20). Their CSF glycine concentrations during life ranged from $124-20.3 \mu \mathrm{mol} /$ liter. and from $82-93 \mu \mathrm{mol} /$ liter. respectively (34 control infants $=5.2+2.0 \mu \mathrm{mol} / \mathrm{lit}(\mathrm{r})$.

Paticnt $3(21)$ was born at term after an uneventful pregnancy. and he appeared to be normal during the first $48 \mathrm{hr}$ of life. Thereatter he became listless and fed poorly. and by the age of $72 \mathrm{hr}$ was markedly hypotonic and apneic. Plasma glycine on the 11 th day of life was $2027 \mu$ mol/liter (normal $=204 \pm+6$ $\mu \mathrm{mol} / \mathrm{liter}$ ). and the (SF glycine concentration was $342 \mu \mathrm{mol} /$ liter. This infant died on the 13 th day of life. His only sibling had developed a similar illness on the 3 rd day of life and had died on the sth day. hut biochemical studies had not been undertaken.

Pattient $f(21)$ was normal at hirth. hut she became ill at the age of $34 \mathrm{hr}$, and died at 32 days after a course characterized by lethargy. proceeding to coma and scizures. Plasma glycine concentrations ranged from 152-13.50 $\mu \mathrm{mol} / \mathrm{liter}$, and (SF glycine concentrations varied between 181 and $30(0) \mu \mathrm{mol} / \mathrm{liter}$. A sister of patient + had died previously at the age of 8 datys with proven hyperglycinemia.

Patient 5 (21) was normal at birth, but he developed neuro- 
logic symptoms by the age of $72 \mathrm{hr}$, and died at 18 days. His plasma glycine concentrations ranged between 116 and 1752 $\mu \mathrm{mol} /$ liter. and his (SF glycine concentrations ranged between 81 and $267 \mu \mathrm{mol} /$ liter.

Tissues were also obtained at autopsy from four control infants. Two of these infants died without evidence of any metabolic disorder. Control infant 3 had a hyperglycinemia of undetermined type, but showed no neurologic symptoms (20). Control infant $f$ died at the age of 2 months with hyperglycincmia secondary to methylmalonic acidemia. The latter diagnosis was confirmed by gas chromatographic demonstration of methylmalonic acid in the infant's urine, and by absence of methylmalonyl mutase apoenzyme activity in a specimen of the infant's liver obtained 2 hr after death (21).

Brain and liver specimens were obtained at atutopsy from the five glycine encephalopathy patients and the four control infants (22) within 1-9 hr after death. and were kept frozen at $-80^{\circ}$ until amino acid analyses and enzyme assatys were performed.

\section{MATHRIALS AND MITHODS}

\section{AMINO A( IDS}

Frozen brain specimens were homogenized and deproteinized with $0.4 \mathrm{M}$ perchloric acid as previously described $(17,18)$. and amino acids and related compounds were yuantitated on a Technicon amino acid analyzer (21). using the single column lithium citrate buffer elution system of Perry et al. (19).

\section{STANI)ARI) GLYCINF. CI.EAVAGIE ENZYME ASSAYS}

Activity of the glycine cleavage enzyme system was determined in vitro by measuring the rate of formation of ${ }^{14} \mathrm{CO}$., from $11^{-14} \mathrm{C} \mid$ glycine, using a modification of the method of Bruin et al. (4). Frozen autopsied brain or liver tissue was homogenized in 10 volumes ice-cold $0.32 \mathrm{M}$ sucrose, using 10 strotes in a motor-driven. Teflon pestle tissue grinder. Reaction mixtures (final volume of $2.55 \mathrm{ml}$ ) contained $12.5 \mu \mathrm{mol}$ Tris-HCl buffer (pH 8.0), $0.5 \mu \mathrm{mol}$ pyridoxal phosphate, $5 \mu \mathrm{mol}$ nicotinamide adenine dinucleotide. $5 \mu \mathrm{mol}$ dithiothreitol. $0.69 \mu \mathrm{mol}$ tetrahydrofolate. $10 \mu \mathrm{mol}$ glycine containing $1 \mu \mathrm{Ci}\left|1-{ }^{14} \mathrm{C}\right| g \mid y c i n e$ (22), and tisste homogenate equivalent to $8-20 \mathrm{mg}$ protein. Protein concentrations were determined by the Lowry method (11).

Incubations were routinely carried out for 30 min at $37^{\circ}$. since preliminary experiments with homogenates of human brain and liver had shown that release of ${ }^{14} \mathrm{CO} .2$ was linear with time for at least $30 \mathrm{~min}$. The ${ }^{1 .}(\mathrm{C})$., released was trapped in NCS Solubilizer and counted for radioactivity in a Packard TriCarb liquid scintillation counter (23). Blank reaction mixtures contained all components except the tissue homogenate, which was replaced by $0.32 \mathrm{M}$ sucrose. All assays were carried out in duplicate or triplicate, and results were corrected for any radioactivity observed in the blanks.

\section{MIXIN(; ANI DIAI YSIS IXXPFRIMFNTS}

Homogenates of brain from control subjects and from glycine encephalopathy patients were mixed in equal proportions in efforts to demonstrate the presence of a possible inhibitor of the glycine cleavage enzyme system in the patients' brains. Mixing was done immediately before enzyme assay in some experiments. whereas in others, the mixed homogenates were stirred at $2^{\circ}$ for 24 or 48 hr before being assayed.

Brain tissue homogenized in 10 volumes ice-cold $0.32 \mathrm{M}$ sucrose, containing $0.5 \mathrm{mM}$ dithiothreitol, was dialyzed at $2^{\circ}$ for 24 or $46 \mathrm{hr}$ against 100 volumes $0.32 \mathrm{M}$ sucrose containing $0.5 \mathrm{mM}$ dithiothreitol in efforts to remove a putative enzyme inhibitor. The dialysate was changed at 12-hr intervals. In these experiments. undialyzed aliguots of the same brain homogenates, which had stood at $2^{\circ}$ during the same intervals. were used to control for deterioration of enzyme activity with time.

\section{EXCHANGE OF CARBOXYI. GROUP OF GI.YCINE WITH ['C]BICARBONATE:}

The conversion of radioactive bicarbonate to radioactive glycine by brain homogenates was assayed by a modification of the method of Motokawa and Kikuchi (13). Reaction mixtures (final volume of $2.6 \mathrm{ml}$ ) contained $125 \mu \mathrm{mol}$ Tris-HCl buffer $(\mathrm{pH} 8 .(1), 0.5 \mu \mathrm{mol}$ pyridoxal phosphate, $10 \mu \mathrm{mol}$ dithiothreitol, $5 \mu \mathrm{mol}$ glycine, $10 \mu \mathrm{mol}$ sodium bicarbonate containing 10 $\mu\left(\mathrm{i}\right.$ of $\mathrm{NaH}^{14}\left(\mathrm{C}_{3}(2+)\right.$, and brain homogenate equivalent to 12 mg protein. The mixtures were incubated at $37^{\circ}$ for $30 \mathrm{~min}$, and the reactions were stopped and the mixtures deproteinized by addition of perchloric acid to give a final concentration of $0.4 \mathrm{M}$. After ${ }^{14} \mathrm{CO}_{2}$ had been released from the acidified mixtures, the denatured protein was separated by centrifugation. and the excess perchlorate was removed by addition of potassium hydroxide (17).

Each reaction supernatant was then subjected to preparative chromatography on the amino acid analyzer (19), with collection of the zones of column effluent in which serine and glycine were eluted. These two effluent zones were then dried in a vacuum desiccator, dissolved in a small volume of water and Aquasol, and their radioactivity counted in a scintillation counter.

PREPARATION OF SOLUBIIIZED GI.YCINE CLEAVAGE ENZYME FROM BRAIN

Frozen brain tissue was ground to a fine powder in liquid nitrogen with use of a mortar and pestle, and was then lyophilized. The dry brain powder was next homogenized with 40 volumes acetone at $-15^{\circ}$ in a Teflon pestle glass homogenizer. and was centrifuged at $4000 \times g$ for $10 \mathrm{~min}$ at $-15^{\circ}$. The precipitate was washed 3 times with 3 volumes precooled acetene, and was then dried in a vacuum desiccator at $-20^{\circ}$. The dry acetone-extracted brain powder was then stirred for 30 min it $2^{\circ}$ with 15 volumes $0.32 \mathrm{M}$ suerose containing $0.5 \mathrm{mM}$ dithiothreitol. The suspension was centrifuged at $16.000 \times g$ for $10 \mathrm{~min}$, and the sucrose extraction was repeated on the pellet. After centrifugation. the two supernatants were combined and were dialyzed for 2 hr at $2^{\circ}$ against 100 volumes 0.32 $\mathrm{M}$ sucrose containing $0.5 \mathrm{mM}$ dithiothreitol.

\section{PREPARATION OF BACTERIAL GIYYCINE CLEAVACIE ENZYME FRAC. TIONS}

The P.T.L-protein and H-protein fractions of a bacterial glveine cleatrage complex were prepared from A. globifermis. strain $1.350(25)$. using the methods described by Kochi and Kikuchi $(8)$. These methods employ ammonium sulfate precipitation of proteins from a crude bacterial extract. followed by at separation of the proteins on a DEAL-cellulose column washed with $0.02 \mathrm{M}$ potassium phosphate buffer $(\mathrm{pH} 7.1)$ containing increasing concentrations of NaCl. Proteins eluted with buffer containing $0.2 \mathrm{M} \mathrm{NaCl}$ were designated P.T.L-protein. and protein cluted with buffer containing $0.5 \mathrm{M} \mathrm{Na}$ (1 was designated H-protein (8).

\section{BRAIN-BAC "IIERIAI INZYMIE RI:COMBINATION FIPI RIMINTS}

Enzyme assitys were carricd out with combinations of the solubilized glycine cleavage complex from human bratin (1.0) $\mathrm{ml})$ and bacterial enzyme protein fractions $(0.5 \mathrm{ml})$. The conditions for these recombination assays were the same as described previously for the standard glycine cleavage assay on brain and liver homogenates. except that incubations 1 ere for 30 min at $3.3 .5^{\circ}$. midway between the temperatures optimal for the bacterial glycine cleavage system $\left(30^{\circ}\right)$ and the human system $\left(37^{\circ}\right)$.

\section{()R(INNIC A(II)S}

Urine and plasma specimens from the glycine encephalopathy patients were acidified to pH 1.0 and extracted inte ethyl 
acetate. The extracted organic acids were methyl esterified and subjected to gas chromatography in a search for organic acids known to be associated with hyperglycinemias (6).

In a specific search for glyceric acid. other ethyl acetate extracts of acidified urine and of acidified brain (deproteinized in 80\%; ethanol) were treated with Tri-Sil/BSA (26) to form the trimethylsilyl derivatives of organic acids. An internal standard of $54 \mu \mathrm{g}$ (1-toluic acid (27) was added to each of the derivatized samples. These were then analyzed on an I.KB$9(0) 0$ gas chromatograph-mass spectrometer $(28)$ fitted with a glass column $(2 \mathrm{~m} \times 6 \mathrm{~mm})$ packed with 6 ; $;(2 \mathrm{~V}-101 \mathrm{an} 100$ 120 mesh Chromosorb W HP and operated isothermally at $152^{\circ}$. During the chromatography of each derivatized extract. the intensities of ions m/e 189 and 193 were monitored. These ions represented, respectively. the $M^{+} \cdot-\left(\right.$ HCOOTMS $\left.+\mathrm{CH}_{3}\right)$ fragment of glyceric acid. and the $M^{-}-\left(H_{33}\right.$ fragment of (1) toluic acid. The quantities of glyceric acid contained in the original urine and brain specimens before extraction were then estimated from the measured ratios of the intensities of $\mathrm{m} / \mathrm{e}$ $189-193$. and the relative increases produced in these ratios when known amounts of glyeeric acid were added to samples before extraction.

\section{RESUITS}

\section{GLYCINF: CONTLNT OF BRAIN}

The content of glycine was markedly elevated (2- to 8 -fold) in all examined regions of autopsied brain from the glycine encephalopathy patients. as compared to the same regions of hrain from four control intants (Table 1). It is particularly noteworthy that glycine content was normal in the brain of control infant + who died with hyperglycinemia secondary to methylmalonic acidemia. The glycine content of brain rises steadily for 24-48 hr after death. iargely hecause of the hydrolysis of glutathione. Thus the glycine values shown in Trible ! are probably somewhat higher than they were during life. However. the brain of glycine encephalopathy patient 3 was removed and frozen within $1 \mathrm{hr}$ of death. and this patient's glycinc clevation in brain must have been almost as striking during life. Fxcept for glycine, the contents of all amine acio and related compounds. serine included. Were normal in the brains of the glycine encephalopathy patients.

\section{GLYCINE CLEAVAGE ENZYME ACTIVITY IN TISSUES}

Table 2 shows the glycine cleavage enzyme alctivities found in frontal cortex, cerebellar cortex, and liver of the control infants and the glycine encephatopathy patients. No radioactive glycine was converted to ${ }^{14} \mathrm{C}()_{2}$ in the hrains of these patients. although some glycinc cleavage enzyme activity wat clearly present in their livers at autopsy. Control infant $\bar{f}$. who died from methyl-

malonic acidemia. had higher glycinc deavage activity in his brain than did either of the other control infants, or several control adults whose brains we have assaved.

\section{SIAARCH FOR POSSIBLI: INAYMIL INHIBITOR IN BRAIN}

Homogenized brain from calch of the glycinc encephalopathy patients wats mixed with homogenate of control infant brain in efforts to demonstrate a possible enzyme inhibitor in the patients brains. Whether the homogenates were mixed immediately before enzyme assilys, or were stirred together at $2^{\circ}$ for $24-48$ hr before assays. no convincing evidence could be found for inhibition of the control infint's glycine cleavage enzyme system. The amounts of "'(C). formed by such mixtures were usually similar to those formed by the same amounts of control brain homogenate assilyed alone.

Table 3 shows the results of a typical dialysis experiment. When homogenate of brain from a control infant was assayed immediately after homogenization, and again after 24 and 46 hr of dialysis, glycine cleavage enzyme activity increased appreciably. That this heightened enzyme activity was not due to contamination by Mycoplasma or other microorganisms was shown by the failure of enzyme activity to increase in homogenates stirred in the same cold room for the same periods. We

Table 2. Glycine cleav'age enzyme activity in brain and liver'

\section{Subjects ${ }^{2}$}

Control l (2 days, $2 \mathrm{hr})$

Control $2(8 \mathrm{mo}, 5 \mathrm{hr})$

Control 3 (hyperglycinemia,? type)

$(14 \mathrm{mo}, 4 \mathrm{hr})$

Control 4 (methylmalonic acidemia) ( $2 \mathrm{mo}, 2 \mathrm{hr}$ )

Glycine encephalopathy $I$

(10 mo. $3 \mathrm{hr}$ )

Glycine encephalopathy 2 ( $8 \mathrm{mo}, 9 \mathrm{hr})$

Glycine encephatopathy 3

( 1.3 days, $1 \mathrm{hr})$

Glycine encephalopathy $t$ (1 mo. 2 hr)

Gilycine encephalopathy 5 ( 18 days, $3 \mathrm{hr}$ )

'Activity expressed as nanomoles of ${ }^{1+} \mathrm{CO}_{2}$ formed per hr per $g$ of protein.

"Figures in parentheses indicate alge at death, and interval from death until tissuc was frozen at $-80^{\circ}$.

"Precise cortical region not identified. probably frontal.

Table 1. (ilycine content of se'veral regions of autopsied brain ${ }^{1}$

\begin{tabular}{|c|c|c|c|c|c|c|c|}
\hline Subjects ${ }^{2}$ & $\begin{array}{l}\text { Frontal } \\
\text { cortex }\end{array}$ & $\begin{array}{l}\text { Occipital } \\
\text { cortex }\end{array}$ & $\begin{array}{l}\text { Cerchellar } \\
\text { cortex }\end{array}$ & $\begin{array}{l}\text { Catudate } \\
\text { nucleus }\end{array}$ & $\begin{array}{l}\text { Putamen } \\
\text { globus } \\
\text { pallidus }\end{array}$ & & $\begin{array}{l}\text { Cervical } \\
\text { cord }\end{array}$ \\
\hline Control / ( 2 days, 2 hr) & 1.6 .5 & 1.82 & 1.74 & 1.69 & 2.11 & & 1.88 \\
\hline Control $2(8 \mathrm{mo} .5 \mathrm{hr})$ & 2.09 & 2.01 & 2.61 & 2.44 & 2.36 & & 2.22 \\
\hline Control 3 (hyperglycinemia. ? type) $(1+\mathrm{mo}, 4 \mathrm{hr})$ & 2.04 & 1.97 & 2.02 & & 2.18 & & \\
\hline Control $\neq$ (methylmalonic acidemia) $(2 \mathrm{mo} .2 \mathrm{hr})$ & 0.93 & 1.07 & 1.45 & & 0.9 .3 & & 2.14 \\
\hline Glycine encephalopathy $/(10 \mathrm{mo}, 3 \mathrm{hr})$ & 4.51 & 3.5 .5 & 10.05 & & 7.4 .3 & & 8.90 \\
\hline Glycine encephalopathy $2(8 \mathrm{mo}, 4 \mathrm{hr})$ & 4.84 & 4.24 & 8.1 .3 & & 8.40 & & 8.33 \\
\hline Glycinc encephalopathy 3 (13 days. 1 hr) & 11.29 & 14.24 & 17.66 & 1.3 .07 & 12.30 & & 14.66 \\
\hline Glycinc encephalopathy $4(1 \mathrm{mo}, 2 \mathrm{hr})$ & $4.84^{: 1}$ & & & & & & \\
\hline Glycine encephalopathy $5(18$ days. $3 \mathrm{hr})$ & $2.92^{3}$ & & & & & & \\
\hline
\end{tabular}


think that the increase in glycine cleavage activity in the dialyzed control brain may have been due to removal of some endogenous inhibitor(s) normally present in brain. However. when homogenate of brain from a glycine encephalopathy patient was similarly dialyzed. no enzyme activity whatsoever was detectable after 24 and $46 \mathrm{hr}$.

\section{ORGANIC ACIDS IN URINE: AND BRAIN}

We found no unusual organic acids in the urines of glycine encephalopathy patients $l, 2$, and 3 . Urine specimens were not available from patients 4 and 5 , but patient 4 was reported (21) not to have had propionic, methylmalonic, or isovaleric acid in her urine. Since an abnormally high glycine concentration has been reported in the (SF of a single patient with D-glyceric acidemia (9). the urines of patients $I$ and 3 , and the brains of patients 3,4 , and 5 were also carefully examined for glyceric acid by combined gas chromatography-mass spectrometry. Table 4 shows the amounts of glyecric acid found in these urine and brain specimens. The concentrations of glyceric acid in the urines of patients $I$ and 3 were about 3 orders of magnitude lower than Kolvrat e' al. (9) fourd in the urine of their patient with D-glyceric acidemia. Very small amounts of glyceric acid were present in the brains of glycine encephalopathy patients 3 . 4 , and 5, but a comparable amount was also present in the brain of control infant 4 , who had methylmalonic acidemia.

\section{CONVERSION OF BICARBONATE TO (IIYCINE} BY BRAIN HOMOCIENATES

The glycine cleavage enzyme system in human brain is probat bly similar to that which has been isolated from rat liver mitochondria by Motokawa and Kikuchi (13-15), and from $A$. globiformis by Kochi and Kikuchi (8). Both of these enzyme systems are composed of four protein components. which the Japanese investigators have named P-. H-. T-. and L-proteins, respectively. Figure 1 illustrates the four reversible reactions in which these enzyme proteins participate. The release of ${ }^{14} \mathrm{CO}$ from $\left[1-^{-14} \mathrm{C} \mid \mathrm{glycine}\right.$ in the in vitro assay that we have employed actually measures only the sum of the first two reactions. Since these reactions are reversible. brain homogenates should form radioactive glycine from $\mathrm{NaH}^{14} \mathrm{CO}_{3}$, if the first or P-protein. and the second or $\mathrm{H}$-protein. are functioning normally. When a homogenate of control infant brain was incubated with radioactive bicarbonate and unlabeled glycine. radioactive glycine was formed at a rate of $164 \mathrm{nmol} / \mathrm{hr} / \mathrm{g}$ protein. On the other hand. no radioactive glycine at all was formed when brain homogenate from a glycine encephalopathy patient was similarly incubated. No radieactive serine was formed in either experiment. Failure to) produce radioactive glycine from radioactive bicarbonate indicates that the enzyme deficiency in glycine encephalopathy must involve one or both of the first two proteins in the system.

\section{BACTIRIAL-BRAIN ENZYME: RECOMBINATION}

P-protein isolated from A. globiformis is capable of participating in glycine cleavage with the other three components isolated from rat liver mitochondria $(8)$. With the procedure we used (8). bacterial P-protein is obtained combined with 1 - and Lprotein, whereas bacterial H-protein is obtained as a separate fraction. Bacterial and mammalian $\mathrm{H}$-protein is heat stable. whereas $P_{-}$. T- and L-proteins are rapidly inactivated by heating. Table 5 shows the cleavage of glycine to $\mathrm{CO}_{2}$, which occurred when bacterial P.T.L and $\mathrm{H}$ fractions were combined with the solubilized brain enzyme system obtained from a control subject's brain. and from a glycine encephalopathy patient's brain. The bacterial P.T,L fraction and the bacterial $H$ fraction (heated to destroy any contaminating P-protein) were inactive by themselves, but readdily cleaved glycine to $\mathrm{CO}_{2}$, when combined. Bacterial P.T.L fraction together with heated control brain cleaved glycine to $\mathrm{C}^{\mathrm{O}} \mathrm{O}$, . thus demonstrating the presence of H-protein activity in control brain. However, no $\mathrm{CO}_{2}$ was

Table 3. Glycine cleatage e'nzyme activity in dialyzed brain homogenates'

('ontrol infant 2

$\begin{array}{ccc}\text { Time } & \text { Stirred } & \text { Dialyzed } \\ 0 \mathrm{hr} & 207 & 2017 \\ 24 \mathrm{hr} & 206 & 357 \\ 46 \mathrm{hr} & 174 & 391\end{array}$

(ilycine encephalopathy paticnt 3

$\begin{array}{cc}\text { Stirred } & \text { Dialyad } \\ 0 & 0 \\ 0 & 0 \\ 0 & 0\end{array}$

1 Homogenates were stirred or dialyed at 2 . Ensme activity is expressed in nanomoles of ${ }^{1+} \mathrm{C}(\mathrm{O}$. formed per hr per ge protein.

Table t. Gilveric acid content of urine and hrain'

$$
\text { Subjects Urine Brain }
$$

Control + (methylmalonic acidemia) $\quad 82 \quad$ of

(ilycine encephalopathy /

7

64

Glycine encephalopathy?

$21 \quad 36$

Giveine encephalopathy $f$

Gilycine encephalopathy 5

1 Gleceric acid content in urine expressed as micrograms per mg creatinine. and in hrain as micrograms per g wet weight. All values are corrected for losses in recovery.

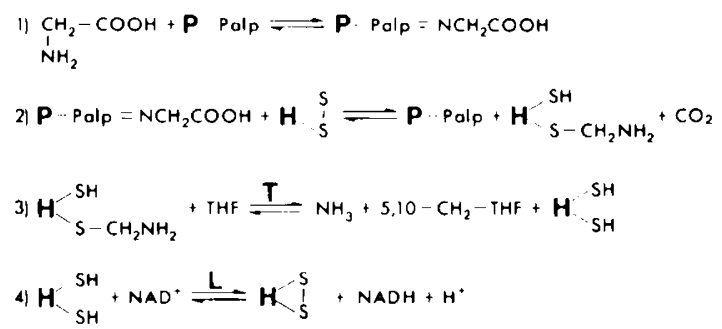

Fig. 1. Diagram of the four reversible reactions in the mammalian glveine cleatrage ensyme system. With the four enzyme proteins designated as $\mathbf{P}, \mathbf{H}, \mathbf{T}$, and $\mathbf{L}$. Palp: pyridoxal phosphate: THF: tetrahydrofolate. Modified from Motokawa and Kikuchi $(15)$

Table 5. Recombination of solubilized glycince clearage complex of control and glycine encephalepathy brain with bacterial P.T.L-, or $H$-protein fractions.'

Protein components

$\left.{ }^{1+} \mathrm{C}_{2}\right)_{2}$ formed

P.I.I

$H^{2}$

P.I.I. and $\mathrm{H}^{\prime}$

Cintrel brain

Control brain' and P.T.I.

Control brain ${ }^{3}$ and $\mathrm{H}^{2}$

Glycine encephalopathy brain

Glycine encephalopathy brainz and P.T.L

(ilycine encephalopathy brain: and $\mathrm{H}^{*}$

0
0
390
11
113
11
0
10
0

1 Results are the means of two assays corrected for any radionctivity observed in the enzyme blanks, and are expressed as counts per min formed for 30 -min incubation at 3.3 .5 "

"Heated in a boiling water bath for 3 min to destroy all ensyme proteins except th-protein.

"Solubilization of the brain enzyme complex results in rapid loss of P-protcin activity. 
formed from glycine when bacterial P.T.L fraction was combined with glycine encephalopathy brain. This suggested that H-protein was absent or inactive in the solubilized enzyme system from the glycine encephalopathy patient's brain.

The failure to form ${ }^{14} \mathrm{CO}_{2}$ when glycine encephalopathy brain and bacterial H-protein were combined does not necessarily mean that $\mathrm{P}$-protein was abnormal in this brain. ${ }^{14} \mathrm{CO}_{2}$ was also not formed when the solubilized enzyme system from control brain and bacterial H-protein were combined. Unlike the isolated bacterial P-protein. which is relatively stable. partially purified mammalian P-protein has been found to be very unstable. It loses $50 \%$ of its initial activity even when stored at $-20^{\circ}$ for as little as $24 \mathrm{hr}(14)$. We did not attempt to fractionate components of the enzyme system from brain. However. even the solubilization of the enzyme system which was required in order to carry out recombination experiments with the bacterial fractions resulted in rapid loss of P-protein activity. Thus, we were unable to prove whether or not P-protein activity was normal in intact brain of glycine encephalopathy patients.

\section{DISCUSSION}

Glycine encephalopathy differs from the ketotic hyperglycinemias, and from other forms of so-called nonketotic hyperglycinemia. in a marked elevation of the glycine content of the brain. which is in turn reflected in an abnormally high concentration of glycine in the CSF. This is illustrated by the high brain glycine levels in our five patients, as well as by the elevated brain glycine values found in a single patient by Bachmann et al. (3). On the other hand, brain glycine values at autopsy were normal in a single patient with hyperglycinemia secondary to propionic acidemia (2), and in our hyperglycinemic infants with methylmalonic acidemia and with an undetermined type of hyperglycinemia (Table 1).

It is possible that the high levels of glycine in brain in glycine encephalopathy are directly responsible for the severe neurologic symptoms characteristic of this disorder. Glycine probably functions as an inhibitory neurotransmitter in the spinal cord. and possibly at certain synapses in the brain as well (10), and a great excess of such a transmitter might well disrupt brain activity. A deficiency of $\mathrm{N}^{5}, \mathrm{~N}^{11}$-methylenetetrahydrofolate (Fig. 1. reaction .3) seems much less likely to be the neurotoxic factor in glycine encephalopathy, since other pathways lead to the formation of this folate intermediate.

Comparison of in vitro glycine cleavage enzyme activity in brain and liver homogenates of glycine encephalopathy patients shows a complete absence of activity in brain. whereas enzyme activity in liver is reduced, but still readily measured (Table 2). This difference between brain and liver is unexplained. It could be accounted for if a necessary activator of the glycine cleavage system failed to penetrate into brain. but was present in reduced amounts in liver, or if a relatively lipid-soluble inhibitor of the enzyme system accumulated in greater amounts in brain than in liver.

Failure of the carboxyl group of glycine to exchange with $\mathrm{NaH}^{14} \mathrm{CO}_{3}$ in homogenates of glycine encephalopathy brain in vitro demonstrates that an enzyme deficiency must exist within the first two steps of the glycine cleavage system (Fig. 1). although it tells us nothing about the integrity of the third and fourth steps. The recombination experiments using atctive Pprotein derived from $A$. globiformis (in the P.T.L fraction). and $\mathrm{H}$-protein derived from human brain suggest that $\mathrm{H}$-protein is inactive in glycine encephalopathy. H-protein derived from rat liver mitochondria. and presumably the $\mathrm{H}$-protein in human brain, is a small protein with a molecular weight of about 17.000. which is heat stable and contains a functional disulfide group in its molecule (13-15). Its function is 10 accept the - $\mathrm{CH}_{2} \mathrm{NH}_{2}$ fragment derived from glycine, and to transfer its one carbon unit to tetrahydrofolate (Fig. 1).

Elevated glycine levels in brain appear highly toxic. although elevated glycine concentrations in plasma seem to be harmless.
This is borne out by our earlier finding (20) that at least one child with marked hyperglycinemia enjoyed reasonable health and was entircly free from neurologic symptoms, whereas an infant who eventually died from glycine encephalopathy repeatedly had normal glycine concentrations in her fasting plasma. A striking feature of glycine encephalopathy is its onset shortly after birth, often on the second or third day of life (16). Why does an infant with this genetically determined disorder do well during intrauterine life, only to become severely ill in the neonatal period? Infants who subsequently develop glycine encephalopathy apparently exhibit normal intrauterine movements, and do not have microcephaly. decreased birth weight. or inactivity in the first few hours after birth.

This suggests that the absence of glycine cleavage enzyme activity in the brain and the reduced enzyme activity in the liver, apparently caused by failure of the H-protein, are not due to a structural abnormality of the apoenzyme. If this were the case, glycine in plasma might cross the placenta into the maternal circulation during fetal life, but glycine should accumulate in the fetal brain and cause brain damage long before birth. It does not seem reasonable to postulate that glycine could be transported freely out of fetal brain up to the time of birth, and then suddenly fail to cross from brain into the circulation after birth. We believe that the best explanation for the sudden onset of glycine encephalopathy early in infancy is either lack of an enzyme activator which might be supplied by the mother during fetal life, or presence of an enzyme inhibitor which is disposed of across the placenta during fetal life. Another possibility is that production of the hypothetical inhibitor commences only at birth in all infants, but the patients with glycine encephalopathy fail to metabolize it further.

The mixing and dialysis experiments that we carried out on brain homogenates have provided no evidence for the presence in the brain of glycine encephalopathy patients of a loosely bound inhibitor of the glycine cleavage enzyme system. However, they have not excluded the possible presence of an inhibitor which is so firmly bound to protein that activity cannot be restored in homogenates of the patients" brains. Addition of brain homogenate containing such a firmly bound inhibitor to a homogenate of normal brain might also not result in inhibition of the active enzyme system in the latter. Daly et al. (5) have recently presented evidence for the existence of onc or more nondialyzable endogenous inhibitors of the glycine cleavage enzyme system in rat brain. so that it is reasonable to envisage the occurrence of such compounds in human brain. It is clear. however, that in our patients glyceric acid was not the putative inhibitor.

Future studies of glycine encephalopathy should perhaps focus on a search for such an endogenous enzyme inhibitor. This hypothetical inhibitor might readily be degraded in normal individuals, but not in affected infants. The latter might be protected by the placental circulation during fetal life, only to have the inhibitor accumulate in liver and especially in brain after birth.

\section{CONCLUSION}

Glycine content was measured in autopsied brain from five infants dying with glycine encephalopathy and four control infants, including two with other types of hyperglycinemia. Activity of the glycine cleavage enzyme system was determined in autopsied brain and liver from these nine infants. Glycine content was elevated 2- to 8 -fold in the brains of the glycine encephalopathy patients. Glycine cleavage enzyme activity was undetectable in their brains, but present at reduced levels in their livers. Dialysis and mixing experiments failed either to demonstrate or to disprove the presence of an endogenous inhibitor of the glycine cleavage enzyme system in the brains of the glycine encephalopathy patients. However. D-glyceric acid was excluded as a possible inhibitor. Failure of brain homogenates from glycine encephalopathy patients to convert radioac- 
tive bicarbonate into radioactive glycine in vitro, as well as the results of recombination experiments with solubilized human brain enzymes and purified protein components of a bacterial glycine cleavage system. showed that the enzyme defect in glycine encephalopathy must involve at least the $\mathrm{H}$-protein of the 4-protein glycine cleavage enzyme system

\section{REIFERINN(TS AND NOTES}

1. Ando, T.. Klingherg. W. G.. Ward. A. N.. Rasmussen, K.. and Nyhan. W. L.: Isovaleric acidemia presenting with altered metabolism of glycine Pediat. Res.. $5: 478(1971)$

2. Ando. T., and Nyhan. W. L... Propionic acidemia and ketotic hyperglycinemia syndrome. In: W. L. Nyhan: Heritable Disorders of Amino Acid Metabor lism. p. 37 (John W'iley \& Sons. New York. 1974).

3. Bachmann. ( .. Mihatsch, M. J. Baumgartner. R. F., Brechbuhler. T. Buhler. U. K.. Olafsson. A., Ohnacker, H.. and Wick. J.: Nicht-ketotische hyperglyzinamie: perakuter verlauf im Neugehorenalter. Hels. Patediat. Acti. 26: $22 x(1971)$

4. Bruin. W. J.. Frantz. B. M.. and Sallach, H. J.: The aceurrence of a glycine cleavage system in mammalian brain. J. Neurochem.. 20: $1649(1973)$

5. Daly. F. (C.. Nadi, N. S.. and Aprison, M. H.: Regional distribution and properties of the glycine cleavage system within the eentral nervous system of the rat: Fvidence for an endogenous inhibitor during in vitro assay. J Neurochem.. 26: $179(1976)$.

6. Hansen. S.. Perry. T. I... Leesk. D.. and Cibson. I..: Urinary hacteria potential source of some organic acidurias. ( lin ( him. Acta. 39; 71 (1972)

7. Hillman, R. 1:. and Keating. J. P.: Beta-ketothiolase deficiency as a catuse of the "ketotic hyperglycinemia syndrome." Pediatrics. 53: 221 (1974)

8. Kochi. H.. and Kikuchi. G.: Mechanism of the reversible glycine cleavage reaction in Arthrohacter glohiformis. I. Purification and function of protein components required for the reaction. J. Biochem. (Tokyo). 75: 1113 (1974)

9. Kolvrata, S., Rasmussen, $K$., and Brande. N. J.: D)-(ilyceric acidemia Biochemical studies of a new syndrome. Pediat. Res.. 10: 825 (1976)

10. Krnjevic, $\mathrm{K}$ : ( hemical nature of synaptic transmission in vertebrates. Physiol. Rev..54: $418(1974)$

11. Lowry, (). H. Roschrough. N. J.. Farr, A. 1... and Randall, R. J.: Protein measurement with the Folin phenol reagent. J. Biol. (hem., 19.3: 26.5 (1951).

12. Morrow. (i.: Methylmalonic acidemia. In: W. I. Nvhan: Heritable Disorder of Amino Acid Metabolism, p. 61 (John Wiley d Sons. New York. 1974)

13. Motokatwa. Y., and Kikuchi, (r.: (jlycine metabolism by rat liver mitochondria. IV. Isolation and characterization of hydrogen carricr protein. an esential factor for glveine metaholism. Arch. Biochem. Biophys.. 1.3.5
$4(1) 2(1969)$

14. Motokiwa $Y$ and kikuchi (; : Cilycine metabolism by rat liver mitochondria. Reconstitution of the reversible glycine cleavage swetem with partially purified protein components. Arch. Biochem. Biophys., 104: 624 (1974)

15. Motokiua $Y$ and Kikuchi. (;.: (ilveine metabolism hy rat liver mitochonddria. Isolation and some properties of the protein-bound intermediate of the reversible glycine cleavage reaction. Arch. Biochem. Biophys.. 164: $6.34(1974)$

16. Nyhan. W. 1... Nonketotic hyperglycinemia. In: W. 1. Nyhan: Heritable Disurders of Amino Acid Metabolism, p. 309 (John Wilcy \& Sons. New York, 1974).

17. Perry. T. L... Berry, K.. Hansen. S., Diamond, S.. and Mok. (. Regional distrihution of amino acids in human brain obtained at autopsy. J. Neurochem... 18: $51.3(1971)$

18 Perry $\mathrm{T}$. l... Hamen. S., and klester. M.: Huntingten's chorea: Deficiency of $\gamma$ aminobutyric acid in bram. N. Engl. J. Med., 28s: 337 (197.3)

19. Perry, T. I... Stedman, D... and Hansen, S.: A versatile lithium buffer elution system for single column automatic amino acid chromatography. J. (hromattugr. 38: tho (1968)

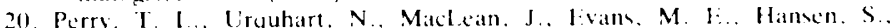
Davidoun. A. (;. F. Applegarth. I). A. Maclecod. P. J. and lock. J. I: : Nonketotic hyperglycinemia: (ilycine accumulation due to absence of glycine cleavage in brain. N. Ingl. J. Med.. 292: 1264)(1975).

21. Technicon Instruments Corporation. Tarrytoun. N. Y.

22. New Fngliand Nucleatr, Boston, Mats

23. Packard Instrument Company, Downers Cirove. Ill

24. IC N Pharmaceuticals. inc., Irvine, ( allif

25. A culture of A ghohiformis was kindly supplied by Dr. Shoichi Takater of Hokkatido University, Japan

20. Pierce (hemical (i). Reckford. Ill.

27. BDH (hemicals, Montreal, Ouebec, (anada.

28. 1 KB Instruments, Rocksille $\mathrm{Md}$

24. We are indebted to Dr. Mate K. Herrick of the Santa (lara Valley Medical (enter. San Jose. Californias, for providing us with specimens ohtained at autopsy from patient ?. and from control infants $I$ and 4. Dr. N. Dingeon of the Hopital Dehrousse. I yon, France, kindly supplied autopsy specimens from patients 4 and 5

30. Procedures used for obtaining autopsy permission. and for preserving the confidentiality of the patients studied, were approved by the University of British (olumbiats (ommittec on Research Involving Human Subjects

31. We acknowledes the villed technical assistance of Mrs. Janet Macl cean.

32. This research was supported by grants 10 Dr. Perry and Dr. Mamer from the Medical Research Council of Canada.

33. Requests for reprints should he addressed to: T. L. Perry, M.1).. Department of Pharmacology. University of British Columbia. Vancouver. British Columbia VoT IW (c anada)

34. Received for puhlication February 14,1977

35. Accepted for publication April 5.1477 